\title{
Use of Formocresol by the Paediatric Dentists across Chennai - A Questionnaire Study
}

\author{
Jaiganesh Ramamurthy ${ }^{1}$, Bhavani Ganesan ${ }^{2}$ \\ ${ }^{1}$ Department of Periodontics, Saveetha Dental College and Hospitals, Saveetha Institute of Medical and \\ Technical Sciences, Saveetha University ${ }^{2}$ Department of Paedodontics, Saveetha Dental College \& Hospitals, \\ Saveetha Institute of Medical and Technical Sciences, Saveetha University.
}

\section{ABSTRACT}

\section{BACKGROUND}

Formocresol is used as medicament for non-vital teeth and primary teeth. In the composition of formocresol, formaldehyde is a primary component which is the hazardous substance. Studies have proved that the use of low dose of formaldehyde in the composition of formocresol would not be carcinogenic. There is a controversy about formocresol in paediatric dentistry for more than 20 years. We wanted to assess the application of formocresol for deciduous teeth and permanent teeth pulpotomy and understand the awareness towards the diluted form of formocresol and its adverse effect among Chennai paediatric dentists.

\section{METHODS}

A questionnaire was given to 50 paedodontists from Chennai city. The questions were based on the usage of original strength or diluted form of Formocresol by the practitioners, the brand and formula that was applied and in case they use diluted form of formocresol, by what method they diluted it and formulation was achieved and the knowledge about the adverse effects. Data was analysed statistically to achieve the results.

\section{RESULTS}

Most of the dentist were aware of the fact that the formocresol has carcinogenic effect. Higher number of dental practitioner were using diluted form of formocresol. Many dentist weres using commercially available formocresol. $64 \%$ of the dentists were using formocresol as intracanal medicament. $24 \%$ of the dentists were using full concentration of formocresol and $54 \%$ were using dilute form of formocresol.

\section{CONCLUSIONS}

This survey concluded that formocresol is a widely used medicament and it is used as commercially available diluted form by most of the practitioners.

\section{KEY WORDS}

Formocresol, Paediatric Dentistry, Hazards, Carcinogenic, Pulpotomy
Corresponding Author: Dr. Jaiganesh Ramamurthy.

Saveetha Dental College and Hospitals, Saveetha Institute of Medical and Technical Sciences, Saveetha University, Chennai. 162 PH Road, Chennai,

Tamil Nadu, India.

E-mail: dr.r.jaiganesh@gmail.com

DOI: $10.14260 /$ jemds/2020/631

How to Cite This Article:

Ramamurthy J, Ganesan B. Use of form cresol by the paediatric dentists across Chennai - a questionnaire study. J Evolution Med Dent Sci 2020;9(39):2884-2888, DOI: 10.14260/jemds/2020/631

Submission 13-11-2019,

Peer Review 18-08-2020,

Acceptance 25-08-2020,

Published 28-09-2020.

Copyright (C) 2020 Jaiganesh Ramamurthy, et al. This is an open access article distributed under Creative Commons Attribution License [Attribution 4.0 International (CC BY 4.0)] 


\section{BACKGROUND}

Pulpotomy is a procedure in which decayed primary tooth with pulp involvement is treated by removing the coronal portion of the pulp and placing medication over the remaining pulp. It is done to facilitate healing and eradicate the remaining bacteria from the pulp and preserve the primary tooth till its exfoliation period. It is basically a partial devitalisation treatment and induction of remaining pulp for regeneration. Some authors prefer mummification term to refer pulpotomy. It was by a researcher called Sweet who introduced two step pulpotomy technique in which coronal pulp was removed and radicular pulp was sterilized by chemicals. It prevented root resorption and infection. Later he reduced the procedure into a single step procedure. In paediatric dentistry, Buckley was the first person who introduced Formocresol as a medicament and to treat the non-vital permanent teeth in 1904. In 1930, Sweet introduced the formocresol pulpotomy medicament for primary teeth. ${ }^{1}$ Later researchers like Redig changed the procedure duration to five minutes which is again controversial. Use of Formocresol is more controversial than Rotherham medicaments. Other pulpotomy medicaments such as ferric sulfate, Glutaraldehyde, calcium-hydroxide, MTA, Bioactive glass, morphogenetic protein are used in the treatment of primary pulpotomy. ${ }^{2} 19 \%$ formaldehyde and 35 $\%$ tricresol, $15 \%$ glycerine and $31 \%$ water base are the composition of formocresol. ${ }^{3}$ In the composition of formocresol, the Formaldehyde is the major component which is a hazardous substance. This is the centre of controversy in paediatric dentistry for more than 20 years. ${ }^{4}$ If at a concentration of $20 \mathrm{ppb}$ (parts per billion) or higher of formaldehyde which leads to health problem given by National Institute of Occupational Safety and Health in USA state. ${ }^{5}$ The International Agency for Research on Cancer (IARC) stated that formalin causes nasal and paranasal sinus carcinoma. ${ }^{6}$ The Dilution 1:5 gives effective results given by Morawa in 1975. Some of the studies on formocresol therapy said the clinical success ratio varies between $70 \%$ and $90 \%{ }^{6}$ Formocresol is safe medicament, ${ }^{7}$ when it use as diluted form and reduced formaldehyde concentration.

\section{Carcinogenicity of Formocresol}

Formocresol is a medicament which has carcinogenic agent. The carcinoma develops after inhalation of aroma with high concentrations of formaldehyde which contains formocresol, which was found from the experimental animals. These cancer occurs as an outcome of long duration direct contact between Formaldehyde and affected tissue. ${ }^{8}$ However, these high-dose formulations are unlikely to occur at sites far away from the point of initial formaldehyde contact like bone marrow, because, according to majority of researchers around the world, formaldehyde is not delivered to these far off areas. Researchers who were against the prolonged use of formocresol among paedodontist on the basis that formaldehyde could lead to carcinoma have failed to understand this very important aspect.9,10

\section{Immune Sensitization}

The formocresol can produce antigenic activity in dental pulp tissue which was found out from the dog,11,12 and also found no increase in rate of immune reaction or allergic response in children who had been treated with formocresol pulpotomy. ${ }^{13}$

\section{Objectives}

To assess the use of Formocresol for primary teeth and permanent teeth pulpotomy and assess the awareness towards the diluted form of Formocresol and its adverse effects among Chennai paediatric dentists.

\section{METHODS}

This is a cross sectional study. A questionnaire was given to 50 paedodontist from Chennai city. The questionnaire containing 10 questions which was based on question that the practitioners used original form or diluted form of Formocresol, the commercial name and formulation they use and in case it was diluted Formocresol, what was the method of dilution of formocresol and the knowledge about the adverse effects. The data was analysed based on the percentage of the dentists selected the given options in the questionnaire. The questionnaire used in this study is tabulated below:

\begin{tabular}{|c|c|c|c|c|}
\hline Question & Option 1 & Option 2 & Option 3 & Option 4 \\
\hline $\begin{array}{l}\text { Do you use Formocresol for } \\
\text { routine pulp treatment } \\
\text { procedure in primary teeth? }\end{array}$ & Yes & No & - & - \\
\hline $\begin{array}{l}\text { If not, what medicament was } \\
\text { used and why? }\end{array}$ & - & - & - & - \\
\hline $\begin{array}{l}\text { Do you use formocresol as } \\
\text { intracanal medication? }\end{array}$ & Yes & No & - & - \\
\hline $\begin{array}{l}\text { What concentration of } \\
\text { formocresol do you use? }\end{array}$ & Yes & No & - & - \\
\hline $\begin{array}{l}\text { Are you using Formocresol for } \\
\text { pulpotomy in permanent teeth? }\end{array}$ & $\begin{array}{c}\text { Full } \\
\text { concentration }\end{array}$ & $\begin{array}{l}\text { Diluted } \\
\text { concentration }\end{array}$ & $\begin{array}{c}\text { Do not } \\
\text { know }\end{array}$ & - \\
\hline $\begin{array}{l}\text { If you are using the diluted } \\
\text { concentration of Formocresol, } \\
\text { then mention the formulation? }\end{array}$ & $1: 5$ & $1: 25$ & $1: 125$ & $\begin{array}{l}\text { Do not } \\
\text { know }\end{array}$ \\
\hline $\begin{array}{l}\text { If you are using the diluted } \\
\text { formulation of Formocresol, } \\
\text { from where it was procured? }\end{array}$ & $\begin{array}{c}\text { Available } \\
\text { commercially }\end{array}$ & $\begin{array}{l}\text { Prepared } \\
\text { chair side }\end{array}$ & $\begin{array}{l}\text { Prepared } \\
\text { by local } \\
\text { pharmacist }\end{array}$ & $\begin{array}{c}\text { Not } \\
\text { available }\end{array}$ \\
\hline $\begin{array}{l}\text { Which medicament is preferred } \\
\text { for regular pulpotomy } \\
\text { procedure? }\end{array}$ & Formocresol & Ferric sulfate & MTA & Others \\
\hline $\begin{array}{l}\text { Have you performed any } \\
\text { clinical study on the } \\
\text { applications and outcomes of } \\
\text { diluted formocresol? }\end{array}$ & Yes & No & - & - \\
\hline \begin{tabular}{|c} 
Do you know formocresol has \\
carcinogenic effects?
\end{tabular} & Yes & No & - & - \\
\hline
\end{tabular}

\section{RESULTS}

\begin{tabular}{|ccc|}
\hline Questions & Yes (\%) & No (\%) \\
\hline Formocresol for routine pulp therapy & 95 & 5 \\
Formocresol pulpotomy in permanent teeth & 78 & 22 \\
Formocresol as intracanal medicament & 64 & 36 \\
Clinical trials on diluted Formocresol & 88 & 12 \\
Do you know Formocresol has carcinogenic effect & 67 & 33 \\
\hline Table 1. Usage of Formocresol among Dentists & \\
\hline
\end{tabular}

Table 1 shows that $95 \%$ of dentists were using formocresol for routine pulp therapy and $5 \%$ of them were not using formocresol. $78 \%$ of dental practitioner were using formocresol for pulpotomy in permanent teeth and $22 \%$ of them were not using formocresol in permanent teeth. $64 \%$ of dentists were using formocresol as intracanal medicament and $36 \%$ of them were not using formocresol as intracanal medicament. $88 \%$ of dentists have done randomized 
controlled clinical trials on the use and application of diluted form of formocresol. $12 \%$ of the dentists haven't done randomized controlled clinical trials on the use and application of diluted form of formocresol. $67 \%$ of them knew that formocresol has carcinogenic effects and $33 \%$ of them didn't know that formocresol has carcinogenic effects.

\begin{tabular}{|cccc|}
\hline Question & Option 1 & Option 2 & Option 3 \\
Formocresol & Full concentration & Dilute concentration & Do not know \\
concentration & $(\%)$ & $(\%)$ & $(\%)$ \\
& 24 & 54 & 22 \\
\hline \multicolumn{4}{|c|}{ Table 2. Concentration of Formocresol Used by Dentists } \\
\hline
\end{tabular}

Table 2 represents that formocresol concentration, $24 \%$ of dentists are using full concentration of formocresol for pulp therapy procedure. $54 \%$ of them are using dilute concentration of formocresol. $22 \%$ of them didn't know the concentration of formocresol.

\begin{tabular}{|c|c|c|c|c|}
\hline Questions & Option 1 & Option 2 & Option 3 & Option 4 \\
\hline \multirow[t]{2}{*}{$\begin{array}{l}\text { Pulpotomy } \\
\text { medicament } \\
\text { preference }\end{array}$} & $\begin{array}{c}\text { Formocresol } \\
(\%)\end{array}$ & $\begin{array}{l}\text { MTA } \\
(\%)\end{array}$ & $\begin{array}{c}\text { Ferric sulfate } \\
\text { (\%) }\end{array}$ & Others (\%) \\
\hline & 66 & 21 & 8 & 5 \\
\hline \multirow[t]{2}{*}{$\begin{array}{l}\text { Dilution formula } \\
\text { knowledge }\end{array}$} & R 1:05 & R 1:25 & R 1:125 & Do not know \\
\hline & 8 & 28 & 10 & 54 \\
\hline \multirow[t]{2}{*}{$\begin{array}{l}\text { Dilution } \\
\text { Formocresol } \\
\text { availability }\end{array}$} & $\begin{array}{c}\text { Commercially } \\
\text { Available } \\
(\%)\end{array}$ & $\begin{array}{l}\text { Prepared by chair } \\
\text { side set }(\%)\end{array}$ & $\begin{array}{c}\text { Prepared by } \\
\text { area } \\
\text { pharmacist (\%) }\end{array}$ & $\begin{array}{c}\text { Not at all } \\
\text { available (\%) }\end{array}$ \\
\hline & 52 & 21 & 4 & 23 \\
\hline
\end{tabular}

Table 3 represents that pulpotomy medicament preference, $66 \%$ of dentists prefer formocresol as medicament for routine pulpotomy procedure. $22 \%$ of them prefer MTA as medicament. $8 \%$ of them prefer ferric sulfate. 5 $\%$ of them prefer some other medicament and also represents that dilution formula knowledge, $8 \%$ of dentists had knowledge of dilution formula of R1:05. $28 \%$ of them had knowledge of dilution formula of R 1:25. $10 \%$ of them had knowledge of dilution formula of R 1:125. $54 \%$ of them do not know the dilution formula. It represents the diluted formocresol availability, $52 \%$ of dental practitioner are using commercially available formocresol, $21 \%$ of them are using chair side preparation formocresol, $4 \%$ of them are using Formocresol which is prepared by local pharmacist. $23 \%$ of them didn't know the diluted formocresol availability.

\section{DISCUSSION}

Primary tooth pulpotomy aims at preserving the tooth till its natural period of exfoliation so that space is preserved for permanent tooth eruption and patient's mastication is not affected due to premature loss of teeth. Various agents have been tried but still lots of controversies arise in selecting the best agent for pulpotomy. Zinc oxide was also used in pulpotomy and to certain extent it was successful and usage of zinc oxide was enormous in dentistry and that could be the reason for testing the same. But eugenol used along with zinc oxide for paste consistency has lot of unwanted effects like irritation. Hence it's used was not appreciated by many dentists. In this study we have assessed the agent formocresol as a pulpotomy agent for primary teeth from experienced dentists. In the present study, $95 \%$ of the dentist were using a formulation called formocresol for primary tooth pulpotomy. Results showed more number of dentists were using formocresol when compared to another study by Yoon RK et al. ${ }^{14}$ In that study, he conducted a survey on best therapeutic methodology for primary teeth vital pulpotomies, in that study $61 \%$ of the dentist used formocresol for primary tooth pulpotomy.14

The present survey showed that most of the dentist are using diluted concentration for primary tooth pulpotomy which is in accordance with the study by King and his associates, ${ }^{14}$ who did a research study on the concentrated forms of Formocresol used by paedodontist in Texas for primary teeth pulpotomy. In that study he found majority of practicing paedodontists were frequently advocating formocresol for primary teeth pulpotomy. This investigation assessed practicing paedodontist about the formulation of formocresol which was used to perform pulpotomies and in case they used diluted form of formocresol, from where they obtained it. Eight-hundred-and-six research studies were assessed by randomly selected group of practicing paedodontists. In that, 422 were received a $52 \%$ response rate. Eighty-four percent of the study population used formocresol for their deciduous tooth pulpotomies. In that, 69 $\%$ of the dentists used original strength, $27 \%$ use diluted and $4 \%$ said not aware. Sources of diluted formocresol for doctors who used the diluted form includes $34 \%$ dentists who bought commercially available ones and $58 \%$ of doctors diluted it on their own and $8 \%$ who had the pharmacy person diluted it. The majority of paediatric dentists who use formocresol for primary tooth pulpotomies used conventional original strength formulation. ${ }^{14}$ In another study, bolt said, Formaldehyde is a reactive ingredient which undergoes highly hazardous reactions with various cellular elements. Carcinogenicity data can be understood on the backdrop of this nature of the chemical. Mice were better able to decrease the irritational effect of formaldehyde than rats and to reduce their respiratory rate when formaldehyde acts on the respiratory tract. Very short exposure of rats to concentrations higher than 2 parts per million inhibits ciliary action of the nasal epithelium. It also lead to progressive histopathological and microstructural lesions at this site. The prevalence of squamous cell carcinomas affecting the nasal epithelium of rats after a period of 2 years inhalation revealed that $14.3 \mathrm{ppm}$ formaldehyde could be due to the result of chronic and repeated local toxicity. This concept is proved by species differentiation in susceptibility to the tissue destruction and mutagenic effect of formaldehyde. Scientific facts on formaldehyde and DNA interaction further support the fact that a direct risk assessment from the formaldehyde effects in rats than those expected for man is highly unlikely. ${ }^{15}$

In this survey, majority of the dentist do not know about the formulation of diluted Formocresol and $66 \%$ of the dentist preferred formocresol for primary tooth pulpotomy than MTA, Ferric sulphate etc. Most of the dentist were using commercially available diluted formocresol for pulpotomy. There was no uniformity or global standards followed in the formulation preparation of Formocresol available commercially as few percentage of the study population who bought the diluted version of the chemical commercially in the marked but was not aware what was the concentration delivered by the factory preparation. In present survey reported that $64 \%$ of the dentist were aware of the fact that 
the formocresol has carcinogenic effect and also low dose of formaldehyde in the composition of formocresol would not be carcinogenic.

The responses to this study revealed that there is abundant knowledge disparity among practitioner regarding the concentration of formocresol as there are lot of changes in the technique employed. More than fifty percent of the dentist know and reported that they were using diluted form of Formocresol. $22 \%$ of them were using original strength because they were not aware about the diluted formulation. More over there is no standardized protocol in the concentration of Formocresol available in the market as some of the doctors who bought the diluted form of the medicament commercially but not aware of the fact that its diluted form or conventional form because supplied didn't mentioned that.

The mechanism of enhanced root resorption with use of formaldehyde is still not clearly revealed. But some authors hypothesized that cell-mediated reaction to normal periodontal tissue by the formocresol irritant, thus initiating or potentiating external root resorption. ${ }^{16-18}$ The presence of chronic inflammation in teeth where pulpotomy was done may also lead to early shedding in a pattern similar to that described for inflamed non-treated primary teeth ${ }^{19}$ Formocresol pulpotomy in primary teeth followed by root canal obliteration has been reported and also calcification changes might be the result of hyper reactive odontoblastic activity following formocresol pulpotomy. ${ }^{20}$ Studies reported decent success rate for mineral trioxide it's not preferred due to technique sensitivity and high cost of treatment.21,22 researchers have also tried using chlorhexidine as pulpotomy agent but with little success only. ${ }^{23}$

Paedodontists who would like to stick on with the use of formocresol should apply the least available dosage possible using a standardised size cotton roll or gauze for the least possible period to get the required beneficial effect. ${ }^{21}$ When used appropriately, Formocresol is relatively a safe medicament that can be used in dentistry. Hence, it would be prudent to suggest and use the diluted form of Formocresol to lower the formaldehyde impact to the young ones.

\section{CONCLUSIONS}

Formocresol is commonly used by paediatric dentists and the majority of them is not aware of the diluted concentrations of formocresol. This study also concluded that there was no clarity about the use of various concentrations of formocresol used in dentistry. This research article focuses on encouraging more researchers to further investigate the appropriate dose and concentration for clinical usage for doing pulpal procedures in primary teeth which has scope for further research.

Ethical clearance was obtained from Institutional Ethical Committee of Saveetha Dental College and Hospitals, Chennai. (IHEC/2018/UG-318)

Financial or Other Competing Interests: None.

\section{REFERENCES}

[1] Ranly DM. Pulpotomy therapy in primary teeth: new modalities for old rationales. Paediatr Dent 1994;16(6):403-9.

[2] Goyal S, Indushekar KR. Use of formocresol by the paediatric dentists across india - a questionnaire survey. Journal of Evolution of Medical and Dental Sciences 2013;32(2):5943-51.

[3] Duggal MS, Curzon ME. Restorative techniques in paediatric dentistry: an illustrated Guide to the restoration of carious primary teeth. $2^{\text {nd }}$ edn. CRC Press 2002:50-63.

[4] Owen BA, Dudney CS, Tan EL, et al. Formaldehyde in drinking water: comparative hazard evaluation and an approach to regulation. Regul Toxicol Pharmacol 1990;11(3):220-36.

[5] Tucker SP. The National Institute for Occupational Safety and Health. (NIOSH) Formaldehyde 2016;4:5-7.

[6] Casas MJ, Kenny DJ, Judd PL, et al. Do we still need formocresal in paediatric dentistry? J Can Dent Assoc 2005;71(10):749-51.

[7] Wright FA, Widmer RP. Pulpal therapy in primary molar teeth: a retrospective study. J Paedod 1979;3(3):195-206.

[8] Milnes AR. Is formocresol obsolete? A fresh look at the evidence concerning safety issues. Paediatr Dent 2008;30(3):237-46.

[9] Cogliano VJ, Grosse Y, Baan RA, et al. Meeting report: summary of IARC monographs on formaldehyde, 2butoxyethanol and 1-tert-butoxy-2-propanol. Environ Health Perspect 2005;113(9):1205-8.

[10] Huang TH, Ding SJ, Hsu TZ, et al. Root canal sealers induce cytotoxicity and necrosis. J Mater Sci Mater Med 2004;15(7):767-71.

[11] Johannsen FR, Levinskas GJ, Tegeris AS. Effects of formaldehyde in the rat and dog following oral exposure. Toxicol Lett 1986;30(1):1-6.

[12] Block RM, Lewis RD, Sheats JB, et al. Antibody formation to dog pulp tissue altered by formocresol uithin the root canal. Oral Surg Oral Med Oral Pathol 1978;45(2):282-92.

[13] Yoon RK, Chussid S, Davis MJ, et al. Preferred treatment methods for primary tooth vital pulpotomies. A survey. N Y State Dent J 2008;74(2):47-9.

[14] King SRA, McWhorter AG, Seale NS. Concentration of formocresol used by paediatric dentists in primary tooth pulpotomy. Paediatr Dent 2002;24(2):157-9.

[15] Bolt HM. Experimental toxicity of formaldehyde. J Cancer Res Clin Oncol 1987;113(4):305-9.

[16] Ranly DM. Assessment of the systemic distribution and toxicity of formaldehyde following pulpotomy treatment: part one. ASDC J Dent Child 1985;52(6):431-4.

[17] Loos PJ, Han SS. An enzyme histochemical study of the effect of various concentrations of formocresol on connective tissues. Oral Surg Oral Med Oral Pathol 1971;31(4):571-85.

[18] Lavanya G, Ganesh J, Subramanian EMG. Application of rotary endodontics in paediatric dentistry-a review of literature. J Pharm Research 2018;12(4):480-3. 
[19] Wilhard MR. Radiographic changes following formocresol pulpotomy in primary molars. ASDC J Dent Child 1976;43(6):414-5.

[20] Primosch RE, Glomb TA, Jerrell RG. Primary tooth pulp therapy as taught in predoctoral paediatric dental programs in the United States. Paediatr Dent 1997;19(2):118-22.

[21] Strange DM, Seale NS, Nunn ME, et al. Outcome of formocresol/ZOE sub-base pulpotomies utilizing alternative radiographic success criteria. Paediatr Dent 2001;23(4):331-6.

[22] Boopanna K, Jaiganesh R, Geo M, et al. Effectiveness of chlorhexidine on patients with periodontitis. Drug Invention Today 2020;13(4):606-10.

[23] Sripradha S, Ramamurthy J, Bhagyalakshmi T. To compare the effectiveness of chlorhexidine extended protection on patients with and without gingivitis - a clinical trial. Drug Invention Today 2018;10(4):3670-5. 